\title{
PSYCHOLOGICAL WELL-BEING OF STUDENTS IN EDUCATIONAL CONDITIONS
}

In Happiness And Contemporary Society : Conference Proceedings Volume (Lviv, March, 20-21, 2021). Lviv: SPOLOM, 2021. P. 110-113. https://doi.org/10.31108/7.2021.24

ISBN 978-966-919-697-2

\section{ПСИХОЛОГІЧНЕ БЛАГОПОЛУЧЧЯ СТУДЕНТІВ В УМОВАХ НАВЧАННЯ}

// Щастя та сучасне суспільство : збірник матеріалів міжнародної наукової конференції (Львів, 20-21 березня 2021 р.). - Львів : СПОЛОМ, 2021. С. 110-113. https://doi.org/10.31108/7.2021.24

ISBN 978-966-919-697-2 
https://doi.org/10.31108/7.2021.24

\author{
FILONENKO Myroslava \\ Doctor of Psychological Sciences, Professor \\ Bogomolets National Medical University \\ Ukraine (Kyiv)
}

KASIANOVA Alexandra

Student, Bogomolets National Medical University

Ukraine (Kyiv)

\title{
PSYCHOLOGICAL WELL-BEING OF STUDENTS IN EDUCATIONAL CONDITIONS
}

\begin{abstract}
The article presents a study of screening the psychological wellbeing of students and the need to develop effective methods of psychological prevention and correction of negative mental states. The analysis of qualitative and quantitative parameters of mood, level of anxiety and depression of students is carried out. The influence of mood on the level of anxiety and depression of the studied students was studied.
\end{abstract}

KEY WORDS: mental health, students, well-being, anxiety, depression, stress.

\author{
ФІЛОНЕНКО Мирослава \\ докторка психологічних наук, професорка \\ Національний медичний університет імені О. О. Богомольия \\ Украӥна (Київ) \\ КАСЬЯНОВА Олександра \\ студентка спечіальності 225 «Медична психологія» \\ Національний медичний університет імені О. О. Богомольия \\ Украӥна (Київ)
}

\section{ПСИХОЛОГІЧНЕ БЛАГОПОЛУЧЧЯ СТУДЕНТІВ В УМОВАХ НАВЧАННЯ}

Важливим завданням сучасної медичної освіти є формування гармонійно розвиненої, фізично та психічно здорової особистості студента, який не лише отримує нові знання, але й має почуватися благополучно в умовах здобуття освіти. Проте на розв'язання цього завдання сьогодні негативно впливають ряд чинників: проблеми нестабільного соціально-економічного становлення держави, складність соціальної ситуації розвитку, внутрішньо сімейна атмосфера та особливості взаємин батьків, рівень професійності та психологічної освіченості викладачів, а також сенситивність студентів до різноманітних соціальних впливів, їхні емоційні нестабільність та вразливість, вікові, індивідуально-типологічні властивості тощо. Окремі $з$ цих чинників детермінують появу у студентів негативних психічних станів, які, при відсутності належної психологічної корекції, адекватних змін умов навчання та виховання, можуть трансформуватись у стійкі властивості особистості 
та деформувати іiі подальший розвиток, стати причиною погіршення успішності навчальної діяльності, поведінки, зумовити порушення взаємин з іншими людьми.

Метою нашого дослідженні $є$ скринінг психологічного благополуччя студентів та необхідності розробки ефективних методів психологічної профілактики та корекції негативних психічних станів.

Психологічне благополуччя ми відносимо до психічних станів і $є$ певною психологічною характеристикою особистості, що відображає іiі порівняно тривалі переживання. До психічних станів відносять прояви почуттів (настрій, афект, тривога), уваги (зосередженість, розсіяність), мислення (сумніви, впевненість) тощо [1, с. 45]. Поряд 3 позитивними (стенічними) станами у людини в процесі іiі життя (діяльності, спілкування) можуть виникати і негативні (астенічні) психічні стани. До негативних відносяться: стани суму, незадоволеності, тривоги, страху, паніки, нудьги, дистресу, відрази, нерішучості, апатії, втоми, байдужості, горя, образи, гніву, стан агресії, сорому, стан емоційного вигорання тощо. Такі стани $\epsilon$ астенічними, вони демобілізують діяльність, призводять до дисгармоній особистісного розвитку, $\epsilon$ вагомим фактором невротизації, можуть перетворитись у стійкі властивості особистості, призвести до соціальної дезадаптації тощо [2, с.27].

Істотною особливістю негативних психічних станів $\epsilon$ те, що базовим станом для їх розгортання $\epsilon$ тривога. При частому повторенні ситуацій чи впливів, які детермінують виникнення тривоги, негативні психічні стани мають здатність переважно легко трансформуватись і закріплюватись у такі негативні психічні властивості як тривожність, дратівливість, агресивність, конфліктність, невпевненість, пасивність тощо. Тривога, у залежності від вроджених, індивідуально-типологічних чинників, особливостей досвіду емоційного реагування та психогенних ситуацій, може по-різному трансформуватись у студентів у такі негативні стани як страх, гнів, агресію, астенію, депресію (субдепресію) та інші.

Завдання нашого дослідження: а) аналіз якісних і кількісних параметрів настрою, рівня тривожності та депресивності студентів; б) дослідити вплив настрою на рівень тривожності та депресивності досліджуваних студентів; в) узагальнити форми роботи психолога із студентами щодо подолання у них депресивних проявів. Дослідженням було охоплено 55 осіб 6 курсу спеціальності "Медицина" Національного медичного університету імені О.О. Богомольця.

Методи і матеріали дослідження: психологічний тест «Як настрій?»; «Шкала тривожності» за Дж. Тейлором; шкала депресії Аарона Т. Бека (BDI).

Обговорення результатів дослідження. За тестом «Як настрій?» у 58,2 \% студентів спостерігався хороший настрій на момент проведення тесту. Це може пояснюватись впливом багатьох сприятливих факторів та задоволенням важливих потреб. 38,2\% мали поганий настрій. До поганого настрою можуть призвести різного роду фізіологічні та соціально-психологічні чинники, які діють на особу на даний момент або протягом не тривалого періоду (поганий сон, погіршення здоров'я, проблеми в сім'і, проблеми в навчанні, неуспішність, проблеми в особистому житті тощо). Характер чинників, що можуть призвести до погіршення настрою визначається індивідуальними психологічними особливостями індивіда. У 3,6\% досліджуваних був виявлений дуже поганий настрій. Дуже поганий настрій можуть спричиняти фактори, що породжують і поганий настрій, але переважно, 
коли комбінуються або діють тривалий період і призводять до наслідків, які впливають на різні сфери життя. Також сильне погіршення настрою має місце під час кризових періодів, наприклад, втрата близької людини, улюбленої роботи, переїзд в інше місто або країну.

У 30,9 \% студентів високий рівень тривожності. Це можна пояснити тим, що студенти на шостому курсі дуже інтенсивно і напружено навчаються, так як це закінчення навчання і на них чекають іспити. Сама ситуація іспиту, коли потрібно прикласти зусилля, завжди таїть в собі невизначеність та суперечність, а отже, $\mathrm{i}$ привід для тривоги. Повністю зняти тривогу можна, усунувши всі труднощі пізнання, але в навчальному процесі зменшити рівень тривогу складно.

Також впливають на стан тривожності індивідуально-психологічні властивості самих студентів. Наприклад, $\epsilon$ студенти в за індивідуальнопсихологічними характеристиками відмічається підвищений рівень тривожності. Також до цих факторів можуть додаватись певні негативні події в особистісному житті, проблеми із здоров'ям та інше. У 29,1\% був виявлений середній рівень тривожності з тенденцією до високого, а в інших 40\% був середній рівень 3 тенденцією до низького, тобто у $69,1 \%$ переважає середній рівень тривожності. Це можна пояснити тим що у кожен студент в кінці навчання відчуває психоемоційне напруження у зв'язку з підсумковими іспитами, які є відображенням їх успіхів у навчанні. За шкалою депресії Бека ми отримали такі результати: у 69,1\% студентів не було виявлено виражених симтомів депресії. У 20\% випадків діагностується легка депресія, у 9,1\% досліджуваних виражена помірна депресія, і тільки $1,8 \%$ було діагностовано виражена депресія. Легка і помірна вираженість депресивного настрою визначається як субдепресивний стан, який може прогресувати у виражену депресію без належної уваги.

Після зіставлення результатів дослідження ми виявили зв'язок між тривожністю та депресією. Ці явища в середовищі студентів часто супутні, проте бувають і винятки. Як правило, вони пов'язані з характером та рівнем мотивації діяльності, стилем поведінки, емоційністю, вимогами до оточення та себе самого. Тривога тут може бути предиспозицією до виникнення депресії або тривало протікати як самостійний стан. Симптоми тривоги та депресії дуже часто схожі між собою, або взаємопосилюються. Було виявлено що більшість студентів не $\epsilon$ тривожними та депресивними. Та була виявлена певна група студентів які $\epsilon$ депресивними та тривожними. Саме в них рівень продуктивності навчальної діяльності є низьким.

Поганий настрій за результами опитування мали $38,2 \%$ студентів, 3 їх числа у $30,9 \%$ був виявлений високий рівень тривожності і у цих же студентів були наявні симптоми депресії (20\% - легка депресія, 9,1 - помірна, 1,8 - важка). У 69,1\% досліджуваних було виявлено середній рівень тривожності (у 40\% середній рівень 3 тенденцією до низького та у 29,1\% 3 тенденцією до високого), у цих же досліджуваних не було виявлено жодних симптомів депресії. У 58,2\% цих студентів був хороший настрій на момент опитування. Дане дослідження підтвердило коморбідність між тривожними та депресивними станами у студентів.

У системі негативних психічних станів студентів, які мають переважно соціально-психологічне походження, провідне місце посідають емоційні негативні стани, які можуть трансформуватись у стійкі властивості особистості та негативно 
впливають на рівень їх благополуччя. Отже, отримані результати дослідження довели, що детермінантами появи та розвитку негативних психічних станів у студентів $€$ індивідуально-типологічні особливості нервової системи та властивості темпераменту.

\section{ЛІТЕРАТУРА}

1. Психологічна енциклопедія / Автор-упорядник О. Степанов. - К.: «Академвидав», 2006. - с.45.

2. Гук Н.С. Оцінка та корекція асихічних станів співробітників органів виконання покарань. Дис.канд. психол. Наук. - К, 199

3. Трикетт, Ш. Как победить депрессию и избавиться от тревоги / Ш. Трикетт. М.: ЭКСМО, 2002. - 160 c.

4. Томчук С.М. Негативні психічні стани молодших студентив та їх корекція: Навчально-методичний посібник. - Вінниця: BCEI Університету „Україна”, 2005. $-95 \mathrm{c}$.

5. Бомба Я. Юнацька депресія (епідеміологічне дослідження) // Журн. невропатол. і психіатр. - 1987. - Т.87. - Вип.10. - С.1501-1503.

6. Левитов Н.Д. О психологических состояниях человека. - М., 2004.

7. Леонова А.Б. Психодиагностика функциональных состояний человека. - М., 1984.

8. E. Diener, S. Oishi, L. Tay, Advances in subjective well-being research. Nat. Hum. Behav. 2, 253-260 (2018)

9. C. D. Ryff, Psychological well-being revisited: Advances in the science and practice of eudaimonia. Psychother. Psychosom. 83, 10-28 (2014)

10. N. L. Sin, S. Lyubomirsky, Enhancing well-being and alleviating depressive symptoms with positive psychology interventions: A practice-friendly metaanalysis. J. Clin. Psychol. 65, 467-487 (2009) 